\title{
The Effects of Blame and Politicization on Responses to Pandemics
}

\author{
Jason Ding ${ }^{1}$ and Dr. Claude Kananack ${ }^{2}$ \\ ${ }^{1}$ Mountain Lakes High School, Mountain Lakes, NJ, USA \\ ${ }^{2}$ University of Exeter, England, United Kingdom
}

$\underline{\text { ABSTRACT }}$

COVID-19 has caused widespread discrimination and blame; however, analyzing history, it becomes apparent that racially motivated blame is common during pandemics. Placed for religious, ethnic, or socioeconomic reasons, blame has caused discrimination and stigma for the "other". Blaming a specific race without scientific evidence causes discrimination and hate crimes, creating more problems that require attention and resources to resolve and diverting them from the pandemic response. A quick and direct response is vital for minimizing the impacts of pandemics, while blame only distracts and leads to politicizing the disease. This paper finds that unfounded blame throughout history results in delays in the health response, inefficient resource allocation, and the undermining of cooperation. This blame is part of politicizing pandemics, which exacerbates the impacts of the disease by diverting attention away from the health response and disease's containment. Racist accusations during pandemics against Asians in America since the turn of the 20th century also led to hate crimes and increased discrimination, resulting in discriminatory public perception reflected even through government actions. COVID-19 is reflecting these historical trends. The latest disease to be politicized, the coronavirus has widened the scope of scapegoating beyond blaming Asians. Its politicization is creating further divisions in society and leading to tension on both a global scale with the WHO and domestically with the $\mathrm{CDC}$ and state legislatures. Consistent with former diseases, unfounded blame during the coronavirus is a practice that ultimately causes more deaths and needs to end immediately.

\section{Introduction}

In December 2019, COVID-19, or the coronavirus, emerged in Wuhan, China. This zoonotic virus was declared a pandemic by the World Health Organization on March 11th, 2020, quickly spreading to nearly every corner of the world and shutting countries down (Safety and Health Topics, 2020). In less than seven months of being labeled a pandemic, COVID-19 has claimed over a million lives and infected more than 33 million people (The New York Times, 2020).

Often in times of crisis, people resort to blaming others. Blame disconnects communities and creates disunity, frequently turning groups against each other and vilifying certain people in the eyes of others. Nowhere is this more evident than with the coronavirus in America, the latest case in a long line of tension caused by misappropriated blame throughout history. The WHO named the virus 'COVID-19', meaning coronavirus disease 2019, specifically to not mention a place or an ethnicity knowing the "stigma" it could imply (The Illness Now Has A Name, 2020). However, some Americans, including the Trump administration, have continued to label the disease the 'Chinese virus', in an attempt to make China the scapegoat for the disease. On May 8th, 2020, UN Secretary-General Antonio Guterres, in 
reaction to labels like the 'Chinese virus', called on political leaders to show mutual respect to everyone and to "take every opportunity to spread kindness" (Lederer, 2020).

Scapegoating has numerous consequences that exacerbate the negative impacts and severity of the disease. Investigating other cases throughout history, there is a clear trend that blaming and victimizing others in times of pandemics is counterproductive, increasing discrimination and hate crimes. The act of blame, which politicizes the disease, also redirects resources, attention, effort, and focus away from dealing with the health problem, potentially delaying the response to the pandemic and making light of the disease. Moreover, politicizing pandemics creates problems that require attention, effort, and time to deal with, all of which instead should be focused on the disease.

Analyzing historical patterns, blame and politicization are prevalent during pandemics and exacerbate its severity and consequences. The modern-day COVID-19 is the latest example of this pattern, with the effects already becoming apparent. It is evident that America's reaction to blame and politicize COVID-19 negatively affects the response effort by redirecting resources and causing response delays, ultimately leading to more deaths.

\section{Methodology}

To write this research paper, I consulted a wide variety of sources. Many sources about past pandemics were examined for contextualization. In order to gain insight into how blame historically creates discrimination during a pandemic, I used sources that focused specifically on the impact on America when unfounded blame was cast against specific groups. Based on a heightened anti-Asian sentiment that occurred due to COVID-19 emerging from China as well as the political rhetoric from the Trump Administration, I also looked specifically for discrimination against Asians in America during past pandemics. I analyzed scientific journals for details on past pandemics, analyzing expert opinions and guidelines regarding the importance of swift and efficient responses to pandemics. Due to the constant unfolding of events, I had to rely on news sources for COVID-19 updates.

To gauge the US government's policy and attitude concerning the COVID-19 pandemic, I looked to modern news sources that reported President Trump and the White House's statements, actions, and attitudes. I used news articles to compare COVID-19 data and containment in various countries, looking at case and death statistics using the most recent data available at the time. When using sources from news websites, I tried to use more objective sources that explained facts or events, including primary sources such as interviews and quotes from government, international, or health officials. To understand the importance of a quick response to a pandemic as well as the impact of delays and discrimination, I looked to medical experts, political scientists, and epidemiologists.

There are, of course, limitations to this research. The data in this paper was collected and written from May to September 2020, while events were still unfolding and as COVID-19 continued to progress. Therefore, I stopped incorporating data before the end of the pandemic and before the end of the Trump presidency. Due to this constraint, the long-term effects of the trends analyzed in this manuscript have yet to reach a natural conclusion. Future research could further test my conclusions by looking to similar sources published more recently to see if the trends in discrimination I identified have continued.

\section{The Prevalence of Blame and the Discrimination It Creates}

Pandemics have a tendency to be blamed on a variety of people. Roy Clark explains in a Harvard publication that religion, ethnicity, and lifestyle are reasons to be subject to discrimination during a pandemic. Since "we are fighting a war against an invisible enemy, ... everyone is a potential suspect", and if you were blamed, "you were dirty, diseased, and evil". The Black Death of the 14th century was often blamed on religious minorities. For example, in Europe, rumors were spread by Christians that Jews were poisoning wells and causing the outbreak, resulting in entire Jewish communities being massacred (Clark, 2020). Syphilis in Hispaniola, the Caribbean island of modern-day Haiti and the Dominican Republic, was blamed on different ethnicities and religions in the 16th century. Although now 
known as originating from the natives, Donald McNeil Jr. (2010) explains in the New York Times that "the Italians were calling it the French pox, the French were calling it the Italian pox, the Dutch were calling it the Spanish itch, the Russians were calling it the Polish disease and the Turks were calling it the Christian disease. Eventually, it was given the Latin name Morbus gallicus, as in Gaul, so the French were stuck holding the linguistic buck". Throughout world history, blame is prevalent whenever there is a disease.

In addition, diseases were often given labels based on their origins. Cholera that came from the Indian subcontinent was called "Asiatic Cholera" by Americans (Suddath, 2010). Other examples of labeling diseases include the "Russian Flu or Asiatic Flu" that originated from Russia in 1889, the "Asian Flu" of 1957 that originated from China, and the "Hong-Kong Flu" of 1968 that originated from Hong-Kong (Khan et al., 2020). Although not directly stating blame, the foundations for discrimination are built by implicating the nation of origin.

In the 19th century, there were instances of cholera outbreaks that were blamed on people based on their nationalities. The 1832 cholera outbreak in New York that originated from Montreal was initially blamed on Canadians. Again in 1866, another cholera outbreak was blamed on Irish immigrants, as "a few of them were sneaking ashore from quarantined ships". An outbreak in Mexico in 1991 was initially blamed on South American cocaine smugglers after a strain from a freighter in Peruvian harbor made its way to Mexico (McNeil, 2010).

Socio-economic and cultural differences were also factors resulting in blame upon certain people for diseases. There is evidence of this occurring during the cholera epidemic in the summer of 1832 in New York City. The city was "more than ever divided by class, religion, and race". The outbreak caused people to flee from the city in large numbers, hitting a place called "Five Points" the hardest, where mostly African-Americans and Irish Catholic immigrants lived. Five Points was a poor urban neighborhood notorious for gangs and violence, described by Charles Dickens as "loathsome, drooping and decayed." Cholera was most prominent in the lower classes, as they had tighter living quarters and little sanitation, with people of the upper class looking down on the infected with a condescending attitude. The wealthy and respected John Pintard wrote that the disease "is almost exclusively confined to the lower classes of intemperate dissolute $\&$ filthy people huddled together like swine in their polluted habitations... those sickened must be cured or die off, \& being chiefly of the very scum of the city, the quicker [their] dispatch the sooner the malady will cease" (Wilford, 2008).

However, we now know that the ways to contract a disease depend on a variety of conditions, such as sanitation and interaction levels among the community, reasons that unfounded blame ignores. Many of the previous examples were during a time when our knowledge of diseases and their transmission were limited by science and technology. However, despite advancements in understanding diseases, the trend of blaming certain people due to their differences continues into the 20th Century.

During the initial discovery of AIDS, those who were contaminated were blamed for contracting the disease due to their lifestyle. According to the founder of Aaron Diamond AIDS Research Center, Dr. David Ho, "it was a repeat of the cholera experience, (as) it was easy to brand the victims and blame the disease on their lifestyle" (Wilford, 2008). When AIDS was found by doctors in America in the 1980s, it was termed the 'gay plague' (Khan et al., 2020), causing hate crimes and discrimination towards the homosexual community. In Chelsea in New York City, gangs had violently attacked homosexuals more than twice the rate of the year before in 1986, including murders specifically targeting homosexuals. The New York City Gay and Lesbian Anti-Violence Project's Executive director stated that they were in the "middle of an epidemic of violence against gay men and lesbians." These trends were similarly found across the country, including San Francisco where violent assaults against homosexuals increased over $20 \%$. A survey across 8 cities found that $20 \%$ of homosexual men "reported having been physically assaulted in their lifetimes because of their homosexuality". Even more disturbing, only around 10\% of violent incidents against gay men were reported to the police (Greer, 1986).

The SARS epidemic in 2003 was discriminated against Asians, as it originated from East Asia. The disease incited a public panic, with dramatic media stories causing a stigma around Asians, causing people to be suspicious of all Asians and hesitant to go near them (Person et al., 2004). This fear resulted in an "informal boycott" of Chinese businesses and empty Chinatowns throughout North America for months. In Toronto, Chinese businesses were 
estimated to have lost from $40 \%$ to $80 \%$ of income that year due to the pandemic. Asians also experienced excess job loss, especially among non-unionized and service workers (Leung, 2020).

Scapegoating diseases facilitates discrimination, resulting in blame that causes hate crimes. Evidently, blame is a counterproductive response that creates more problems, requiring more resources and attention to solve for public health officials and government officials. Clark corroborates, stating that during pandemics, "fears of contagion have a long history of side effects: shunning, casting out, scapegoating, panic, xenophobia, racism, intolerance, demonizing, tribal isolation, building barriers, misinformation, conspiracy theories, excommunication, violence, and even murder" (Clark, 2020).

A common practice whenever there is a disease, blame results in discrimination. From the Black Death to Syphilis to Cholera, scapegoating a group in attempts to place blame for a disease has discriminated against people based on religion, nationality, socioeconomic status, and lifestyle. Even recently, racial discrimination due to diseases, from AIDS to SARS, has resulted in extremely negative effects.

\section{The Discrimination against Asians during Pandemics}

Asian Americans are often subject to violent scapegoating, and racism and xenophobia during pandemics, having a long history in America. In the 19th century, Chinese immigrants were labeled as "barbarians, subpar, uncivilized, unclean". Americans also feared Chinese immigrants based on their different cultural habits. As the population of Chinese immigrants increased in American cities, the immigrants settled in communities called "Chinatown". Several Chinatowns were targeted by Americans during outbreaks of disease (Chow, 2020). The Chinese, considered to be "foul and disgusting" people that "generated unwholesome odors", were blamed for the smallpox outbreak in San Francisco in 1875 by the city health officer, J. L. Meares. He ordered every house in Chinatown to be disinfected, explaining that the "unscrupulous, lying and treacherous Chinamen have disregarded [the city's] sanitary laws and are concealing their cases of smallpox." However, following the fumigation of all of Chinatown, the epidemic continued to spread (Trauner, 1978). During a bubonic plague outbreak in 1900 in Honolulu, Hawaii, officials conducted a controlled burning of Chinatown in the city, as the Asian community was scapegoated for the disease despite evidence that it was spread through rats. "Their possessions were thrown out into the street, their homes sprayed with carbolic acid, and they were forced to shower in public in mass, makeshift cleaning stations." Officials then followed by burning the homes of Japanese and Chinese people. Over 5,000 residents were left homeless, and few ever financially recovered (Working Class History, 2020). When the bubonic plague hit San Francisco that same year, all of Chinatown was quarantined allowing no Chinese person in or out because the disease was thought to have come from ships from Asia. The mayor insisted on separating the Chinese from the others, believing them to be "a constant menace to the public health" (Clark, 2020).

Similarly, in Santa Ana, California, the City Council burnt down Chinatown, with the fire department watching to make sure adjacent buildings of non-Asian communities did not burn. Chinese immigrants were also subject to invasive and humiliating medical exams in San Francisco Bay on Angel Island, where racist views became medicalized (Chow, 2020).

Historically in America, Asians were unjustly blamed for diseases. As a result of their cultural differences, they were subject to public hatred and racist policies enacted by the government, destroying their communities and belongings. This pattern of discrimination against Asians continues into the present-day.

\section{Discrimination during the Coronavirus}

The most recent in a long line of diseases resulting in unfounded discrimination, coronavirus also results in discrimination and blame. Being referred to as the "Chinese Virus" and "Kung flu" by the American Government, the coronavirus has been primarily blamed on Asians (Clark, 2020). This attempt to scapegoat China, according to Asia 
advocacy director at the Human Rights Watch John Sifton, increased "racism and physical attacks on Asians" (Covid19 Fueling Anti-Asian Racism..., 2020).

Scapegoating, often leading to blame, is acknowledged to be counterproductive and only increases the number of problems at hand because it diverts attention from the government and public focus away from the response effort and disease containment. "Naming individual countries [of origin] is not productive," said Dr. Scott F. Dowell, pediatric infectious disease specialist at the United States Centers for Disease Control and Prevention "[where the disease came from] really doesn't matter" (McNeil, 2010). Dr. Jordan Tappero, an epidemiologist with the CDC, said he did not think focusing on the source of the disease "is a good use of resources", as treating victims and saving lives takes priority (Archibold, 2010). Public health officials are primarily focused on the disease's containment.

Singling out China for the spread in America is both scientifically inaccurate and impractical. The "contagion of irrationality" results in the blame on China to be reflected in blaming Chinese Americans, many of whom have never been in China. People are afraid of Asians in public, avoiding restaurants and businesses, hollering racist slurs in public, and destroying Chinese shops and homes (Clark, 2020).

This discrimination against Asian Americans has fueled and translated into a rise of hate crimes. According to a website to report hate incidents set up by Asian advocacy groups, there have been 2,120 hate incidents reported due to the coronavirus on Asian Americans as of June 2020. Around 40\% of these reports were based in California, where hearing racist slurs about the disease have become commonplace (Donaghue, 2020).

The hate crimes against Asians have been so prevalent that there has been legislation drafted as a result. New York congresswoman Grace Meng proposed the "COVID-19 Hate Crimes Act (H.R.6721)", which aims to provide more federal government oversight of coronavirus hate crimes and requires the Department of Justice to provide Congress with updates on reported biased incident status. Her proposition is endorsed by many humanitarian organizations, and she states that "during this pandemic, we have seen a rash of hate-motivated attacks targeting Asian Americans and other marginalized communities.... [that] deserve our support, not hate" (Meng Introduces Legislation..., 2020).

In light of this, UN Secretary-General Antonio Guterres stated how COVID-19 has made apparent "disproportionate effects on certain communities, the rise of hate speech, targeting of vulnerable groups, and the risks of heavy-handed security responses undermining the health response". He further explained how the pandemic creates "“a tsunami of hate and xenophobia, scapegoating, and scaremongering'... 'surg[ing] anti-foreigner sentiment"”, calling on political leaders to show mutual respect to everyone and " take every opportunity to spread kindness"” (Lederer, 2020).

One source for discrimination is the strong correlation between race and severity of COVID-19 in communities, resulting in increased discrimination of black communities. According to Vox, racist policies such as redlining resulted in building polluting infrastructure closer to poorer, minority communities. This has exposed these communities to more harmful pollutants leading to higher levels of respiratory diseases and cancer. When COVID-19 is introduced into communities with high rates of respiratory problems, there is a disproportionate death rate as a result. For example, the disproportional levels of coronavirus severity are seen in Louisiana where people identifying as black are $32 \%$ of the population but $56 \%$ of COVID-19 deaths, and in Michigan where they are $14 \%$ of the population, but $41 \%$ of COVID-19 deaths. As a result, discrimination against minorities spreads from the disproportional rates of contamination and death (Vox, 2020).

The effects of this scapegoating are reflected in the increased discrimination that Asian and African Americans say they have experienced since the COVID-19 outbreak. The Pew Research Center records that 40\% of African and Asian Americans state that people have acted uncomfortable around them since the outbreak. Furthermore, when American adults were surveyed, 39\% of them believe that more people are increasingly racist to Asians since the pandemic and 30\% believe so for African Americans. Research also shows that people are more suspicious of them when they wear a mask in public because of their race. Interestingly, this discriminatory attitude is reflected in the demographics of people who wear a mask, as $83 \%$ of African Americans say they wear masks in public opposed to the $64 \%$ of Hispanic Americans and 67\% of White Americans. Research also shows that African and Asian Americans believe that they are subject to slurs and jokes at a higher rate and fear that they may be attacked or threatened. 
Moreover, minorities are intimidated in their daily lives and are modifying them out of fear that has resulted due to blame from the virus (Ruiz et al., 2020).

Clearly, when there is an outbreak of disease, blame and discrimination are commonplace, focusing on minorities or those considered different, the "other". However, the racially motivated blame from the coronavirus is destabilizing an already tumultuous society and increasing tension at a time when it is already high, resulting in hate crimes against minority racial groups.

\section{The Importance of a Quick Response and Efficient Resource Allocation}

During pandemics, it is imperative that they are dealt with promptly and directly. Streamlined sharing information between governments, doctors, and scientists is vital in organizing a quick containment of the disease to lower cases. It is vital to use science and resources properly to help the infected and ultimately save lives.

When diseases start to spread, a timely response is crucial. Following the 2003 SARS pandemic, the World Health Assembly updated the International Health Regulations as various countries had delayed medical responses. Countries created pandemic plans to be more prepared for the medical crisis, and the WHO aimed towards creating a more cohesive global response and clearer communication between governments. These plans resulted in a quicker response to the 2009 influenza pandemic leading to a more globally coordinated response with improved funding and standards for public health utilities (Madhav et al., 2017).

Despite this quicker response, UNESCO Chair in Bioethics and Human Rights Dr. Campos (2020) discovered from analyzing the 2009 pandemic response even more ways to minimize delays to the health response. In an article published by Cambridge in 2020, she contended that the way the disease was defined in the 2009 influenza pandemic caused confusion and vagueness. The WHO "needlessly included an evaluation of the severity of the 2009 pandemic" and resulted in several week delays of pandemic declaration because the policymakers were focused on determining the severity of the disease. To reduce future delays of this nature, Dr. Burkle proposed a new way of defining pandemics to create a clear hierarchy so that priorities in resource allocation are distinct and logical. Associate Professor at Johns Hopkins Daniel Barnett (2011) reinforces the importance of this proposition, contending that the precise definitions of pandemics have "enormous bearing on planning priorities". In order to remove bias and be direct, Dr. Khan of the University of Missouri agrees that communicating the severity of the disease is vital when preparing resources to combat a pandemic, so a more effective and quick medical response would result in economical resource distribution (Khan et al., 2020).

Resource allocation, as supported from above, is vital when dealing with the disease. As detailed by the WHO's Mass Casualty Management Systems' guidelines from 2007, “the most commonly cited problem in disaster management is invariably communications breakdown, with emergency activities and decision-making being seriously affected by vital information being lost or delayed" (World Health Organization, 2007). Esteemed health specialists Dr. Frederick Burkle and Dr. Greenough (2008) further explains that when medical resources are distributed inefficiently or are delayed, the results are an increase in deaths and a much greater public health issue.

Never is there a greater necessity for clear and objective communication than in crises caused by pandemics. With proper resource allocation so vital in combating diseases, an unacceptable amount of setbacks in disease management were a direct result of unfounded blame.

\section{Historical Context of Delays due to Discrimination, Blame, and Politicization}

A major issue that detracts from an urgent response by diverting resources and attention is when governments, groups, and society politicize blame. The politicization of blame leads to more discrimination, division among society, and downplays the severity of the disease. There are examples of past pandemics proving that the act of politicizing blame 
is detrimental in dealing with the medical emergency at hand and detracts from the prompt response and efficient resource allocation experts have agreed to be so vital.

Politicization during pandemics can lead to the disease being disregarded or degraded as a threat. Connecticut College Professor Jim Downs states that the medical divisions of the Freedom Bureau and the National Archives give evidence of an 1865 smallpox epidemic during the Civil War that significantly affected more black than white people, according to the medical community's nosological reports. The public remained indifferent to this epidemic, as it was mostly black communities that were being affected; therefore, little medical attention and health response effort were given to the pandemic. For instance, when smallpox ravaged through the Union Army controlled New Orleans and Charleston during the Civil War, the disproportionately low effects on white people resulted in the lack of a health response, leading to high transmission rates and intensifying the severity. Instead of helping, racially motivated groups actually promoted images of these ill black communities to portray them as inferior and worthless in an attempt to popularize Jim Crow Laws after the Civil War ended. Downs furthers that white Southerners were "showing black people being sick in an effort to justify segregation in the early part of the 20th century." As a result of smallpox being used for political purposes, the disease's impacts were greatly exacerbated by the unconcerned public opinion (Hammonds \& Downs, 2020).

In contrast, when the cholera pandemic occurred in America only a year after the smallpox epidemic in 1866, the disease was contained much quicker and faster because of the prevalence of the disease in white and not just black communities. According to history and science Professor at Harvard, Evelyn Hammonds, the epidemic's effects on white people gave it more urgency and importance in the eyes of the government and public. As a result, the government deployed medical officials and coordinated a containment plan, leading to a less severe epidemic. Hammonds continues that "the biggest threat to health of any population is apathy, or the sheer unwillingness for people to care" (Hammonds \& Downs, 2020). By politicizing smallpox, public attention was shifted away from focusing on the response to the disease to who the disease impacted through racist views, preventing a well-organized response that helped ease the cholera outbreak one year later. Dr. Thana Campos (2020) corroborates, explaining that public opinion of a pandemic has "substantial practical implications on decision making in global health fieldwork".

Politicizing blame resulted in violence against the UN peacekeepers who the Haitians thought brought cholera to the island in 2010. In response to political conflict in 2004, 12,000 peacekeepers were sent to the island. The UN stated that the Haitians attempted to use this opportunity as an excuse to remove these troops out of the country to destabilize it before the presidential election, furthering that the violent protests were an attempt to create chaos (Archibold, 2010). The example in Haiti shows that there are often political motives behind blame, used in an attempt to strengthen the current government and weaken its opponents inside and outside of the country in this case. Blame diverts responsibility and attention away from the problem itself and can be used as a political weapon to create havoc.

There are more instances of pandemics creating political instability, like when the West Africa Ebola epidemic in 2014 intensified political tensions in Guinea, Liberia, and Sierra Leone. Ruling politicians used the response effort to increase their political control, and their political enemies supposedly obstructed response efforts to promote public outrage, complicating the response efforts to the Ebola outbreak. In Sierra Leone, for instance, "quarantine in opposition-dominated regions was delayed because of concerns that it would be seen as politically motivated". Political scientists agree that pandemics already weaken and destabilize governments, increasing the risk of civil wars and uprisings. (Madhav et al., 2017). Politicizing the Ebola pandemic in West Africa complicated the response and prevention by creating distrust in the government.

Politicizing blame causes delays time and time again throughout history. Whether it be through deceiving public perception of a disease or sparking riots and government dissatisfaction, the politicization of diseases escalates the disease's impacts and intensifies its severity through diverting attention away from an effective health response.

\section{The Worsening Effects of Blame and Politicization on the American Coronavirus Response}


Currently, the politicization of the coronavirus is through the US government and American mass media. Following the lead of President Trump, the WHO and its Director-General Dr. Tedros are scapegoats for the dire situation in the US. President Trump downplayed the severity of the disease, disregarded WHO's safety briefings throughout the early stages of the pandemic, and continued to claim that the media was exaggerating the coronavirus' severity for political purposes (Mahase, 2020). As early as January 2020, President Trump ignored briefings by experts about the potential threat and severity of COVID-19 and continues to ignore their advice. For example, Alex Azar, the US Secretary of Health and Human Services, was disregarded twice about the possibility of a pandemic throughout January and February (Yong, 2020).

On February 28th, President Trump then further politicized the pandemic, accusing the Democrats of "politicizing the coronavirus" calling COVID-19 "their new hoax" while continuing to assure the American public that his administration was "totally prepared" (Egan, 2020).

The US political division regarding the severity of the coronavirus is apparent as seen in a poll from Civiqs, revealing that $60 \%$ of Democrats are extremely concerned about the virus compared to only $12 \%$ of Republican. A 2 $\%$ to $33 \%$ difference is also seen in the "not concerned at all" category by Democrats and Republicans, respectively. Following safety regulations, such as social distancing, is often viewed as a political act, and the politicization of COVID-19 has turned basic gestures of staying safe into controversial actions (Singal, 2020).

The politicization of the pandemic has led many conservatives to distrust the media and the advice of health officials. As a result of the politicization of the virus and blaming the WHO, there is a large distrust in the information released about the virus, resulting in significant differences in beliefs of the severity of the virus. When politicization occurs, following safety guidelines can be seen as a political gesture, exacerbating many difficulties when dealing with the virus.

In the face of mounting cases and deaths, politicizing the disease has led to disagreements over the severity and the extent of government aid required. In Minnesota, there were months of political tension due to the delay of public health funding from the Federal Government. The Democratic governor of Minnesota Tim Walz and the Democratic-majority House clashed with the Republican-majority Senate, lengthening negotiations regarding the release of public health funds. Similarly, a vast majority of local health departments in Missouri were still awaiting relief funds by mid-July. Partisan politics complicated the situation in numerous cities throughout America, resulting in only a quarter of the $\$ 150$ billion coronavirus Relief Fund being spent by June 30th, with politicians in Congress continuing to argue against giving more money to aid local governments' response efforts (Smith et al., 2020).

President Trump has even openly countered the health authorities' guidelines about wearing masks. Minutes after the CDC announced its new mask recommendations, he told reporters at a White House briefing "I don't think that I'm going to be doing it". Trump also told his campaign managers that he believes it would "send the wrong message" to the public (Weissert \& Lemire, 2020).

Wearing a mask in public is also a source of political debate and shows a stark division between political parties. A poll from The Associated Press-NORC Center for Public Health Research published in May reveals that $76 \%$ of Democrats say they wear a mask in public compared to just $59 \%$ of Republicans (Weissert \& Lemire, 2020). Employees who work at the Kroger Company in Michigan in May claimed that they are "downright afraid to ask people to put on masks... it's like asking them to throw their gun away" (Canales, 2020). This mentality was further displayed when a Family Dollar security guard, enforcing the Governor's Executive Order, was shot dead in Flint, Michigan earlier that month after stopping two people without masks from entering the store (Collman, 2020).

This is not a new issue. During the Spanish Flu of 1919, in the US an ad campaign claimed that wearing masks was patriotic, claiming it a noble, civil duty. However, some Americans staged Anti-Mask Protests in anger, forming the "Anti-Mask League of 1919". Tensions similarly increased, and hundreds were arrested for not wearing masks in public, and one health official even shot someone who refused to wear his mask (Canales, 2020).

The politicization of the COVID-19 by the US government not only increases tension and disagreements domestically but also undermines global cooperation. The G7 joint statement on coronavirus was initially rejected 
after the US insisted on referring to the pandemic as the "Wuhan virus", resulting in several other nations releasing their own individual statements (Marquardt, 2020).

The US also blocked another symbol of global unity, a G20 joint statement, because it would have strengthened the WHO. Furthermore, the US blocked a UN Security Council resolution agreement that motioned for a global ceasefire agreement because of frustration with China and the WHO (Atwood, 2020). Despite the country that contributes the most to the WHO, America's funding was frozen by President Trump in April (Mahase, 2020). Trump even threatened to make the freeze permanent and withdraw membership (VOA News, 2020).

This disruption of global cooperation has detrimental effects on everyone. Dr. David Heymann, an infectious disease epidemiology professor at the London School of Hygiene, explained that loss of funding for the WHO could be disastrous. He underscored the importance for countries to forgo geopolitical barriers and that it is essential that "all countries work together very well... it would be disastrous for WHO to lose funding" (Mahase, 2020). WHO Director-General Tedros Adhanom Ghebreyesus stated that "the world is in desperate need of national unity and global solidarity. The politicization of the pandemic has exacerbated it... the greatest threat we face now is not the virus itself. It's the lack of global solidarity and global leadership" (VOA News, 2020).

Trouble communicating results in difficulties in decision-making and undermines the trust of the WHO and global health authorities. Johns Hopkins Associate Professor Daniel Barnett (2011) further stated that decreasing communication and trust minimizes "compliance with essential protective guidance in the face of future threats" and causes "complacency among frontline responders". Trusting the WHO and health authorities is essential when dealing with pandemics, with disastrous impacts of not doing so. Abbigail Tumpey, Associate Director for Communication Science at the CDC, asserts that "trust and credibility can greatly influence (the) ability to persuade affected persons to follow public health authorities' recommendations during an outbreak or public health response. The ability to contain and stop the outbreak might hinge on established relationships and coordination with key partners and stakeholders" (Tumpey et al., n.d.).

Because of politicization, the US response has remained largely unsuccessful and has caused bad consequences. According to an infectious disease specialist at Vanderbilt University, Dr. William Schaffner, "The US response is a textbook example of how to do it wrong". America has based policies on politics rather than science, leading to a less cohesive and clearly communicated response (Ollove, 2020). America's response to the pandemic, as a result of politicization, yields different results than other countries. America's death rate from the coronavirus, when compared to other nations, is staggering. Having only 4\% of the world's population, America is responsible for $22 \%$ of the world's confirmed coronavirus deaths. As of early September, nearly 190,000 people have died of the virus. Had America had the same death rate as its neighbor, Canada, only 81,000 people would have died. When compared to other wealthy nations, these numbers are significantly smaller across the board: 38,000 deaths if America had Germany's death rate, 11,000 deaths if America had Australia's death rate, and only 5,000 deaths if America had the same death rate as Japan (Lopez, 2020).

\section{Conclusion}

Racially motivated blame is common during pandemics, from the Black Death in the 14th century to the HIV/AIDs pandemic of the late 20th century. Placed for religious, ethnic, or socioeconomic reasons, blame has caused discrimination and stigma for the "other" in various forms, from job loss to business boycotts to violent hate crimes.

Blaming a specific race without scientific evidence has a history of causing discrimination and hate crimes, creating more problems that require attention and resources to resolve and diverting them from the pandemic response. A quick and direct response is vital for minimizing the impacts of pandemics, which unfounded blame detracts from. The fallout of racist accusations against Asians in America since the turn of the 20th century led to hate crimes and increased discrimination, resulting in discriminatory public perception reflected even through government actions. This blame is part of politicizing pandemics, which results in delays in the health response, inefficient resource allocation, and the undermining of cooperation, three aspects that experts agree to be so crucial during times of disease 
and unrest. Displayed through diseases from Cholera during the Civil War to Ebola in West Africa in 2014, politicization exacerbated the impacts of the disease by diverting attention away from the health response.

COVID-19 is reflecting these historical trends. The latest disease to be politicized, the coronavirus has widened the scope of scapegoating beyond blaming Asians. Its politicization is creating further divisions in society and leading to tension on both a global scale with the WHO and domestically with the CDC and state legislatures. Consistent with former diseases, unfounded blame during the coronavirus is a practice that ultimately causes more deaths and needs to end immediately.

\section{Acknowledgments}

I would like to thank my research advisor Dr. Claude Kananack for helping me with this project.

\section{References}

Archibold, R. C. (2010, November 17). Officials in Haiti Defend Focus on Cholera Outbreak, Not Its Origins. The New York Times. www.nytimes.com/2010/11/17/world/americas/17haiti.html?scp=9\&amp;sq=cholera\%2BHaiti\&amp;st=cse

Atwood, K. C. (2020, May 9). US blocks UN resolution on coronavirus ceasefire after China pushes WHO mention - CNNPolitics. CNN. https://edition.cnn.com/2020/05/09/politics/us-rejects-un-coronavirus-resolution-china-who/index.html

Barnett, D. J. (2011). Pandemic influenza and its definitional implications. Bulletin of the World Health Organization, 89(7), 539. https://www.who.int/bulletin/volumes/89/7/11-089078.pdf

Burkle, F. M., \& Greenough, P. G. (2008). Impact of Public Health Emergencies on Modern Disaster Taxonomy, Planning, and Response. Disaster Medicine and Public Health Preparedness, 2(3), 192-199. http://dx.doi.org.proxy1.library.jhu.edu/10.1097/DMP.0b013e3181809455

Canales, K. (2020, May 29). The face mask is a political symbol in America, and what it represents has changed drastically in the 100 years since the last major pandemic. Business Insider. https://www.businessinsider.com/masks-political-symbol-coronavirus-covid-19-spanish-1918-flu-pandemic-2020-5? international $=$ true $\& \mathrm{r}=\mathrm{US} \& \mathrm{IR}=\mathrm{T}$

Chow, A. R. (2020, May 20). Violence Against Asian Americans Is on the Rise-But It's Part of a Long History. Time. https://time.com/5834427/violence-against-asian-americans-history/

Clark, R. P. (2020, April 13). When the narrative becomes the disease. Nieman Foundation at Harvard. https://nieman.harvard.edu/stories/when-the-narrative-becomes-the-disease/

Collman, A. (2020, May 5). A Family Dollar security guard was shot dead after trying to enforce Michigan's compulsory face-mask law. Insider. https://www.insider.com/family-dollar-guard-flint-ichigankilled-mask-law-2020-5

Covid-19 Fueling Anti-Asian Racism and Xenophobia Worldwide. (2020, September 30). Human 
Rights Watch. https://www.hrw.org/news/2020/05/12/covid-19-fueling-anti-asian-racism-and-xenophobiaworldwide

DE Campos T. C. (2020). The Traditional Definition of Pandemics, Its Moral Conflations, and Its Practical Implications: A Defense of Conceptual Clarity in Global Health Laws and Policies. Cambridge quarterly of healthcare ethics : CQ : the international journal of healthcare ethics committees, 29(2), 205217. https://doi.org/10.1017/S0963180119001002

Donaghue, E. (2020, July 2). 2,120 hate incidents against Asian Americans reported during coronavirus pandemic. CBS News. https://www.cbsnews.com/news/anti-asian-american-hate-incidents-upracism/

Egan, L. (2020, February 28). Trump calls coronavirus Democrats' 'new hoax.' NBC News. https://www.nbcnews.com/politics/donald-trump/trump-calls-coronavirus-democrats-new-hoax-n1145721

Greer, W. R. (1986, November 23). VIOLENCE AGAINST HOMOSEXUALS RISING, GROUPS SEEKING WIDER PROTECTION SAY. The New York Times. https://www.nytimes.com/1986/11/23/us/violence-against-homosexuals-rising-groups-seeking-wider-protection-say.html

Hammonds, E., \& Downs, J. (2020, April 23). Evelynn M. Hammonds and Jim Downs: "Lessons Not Learned: Smallpox and African Americans in the 1860s." The Hutchins Center for African \& African American Research. https://hutchinscenter.fas.harvard.edu/epidemics-and-health-disparities-3

Khan, U., Mehta, R., Arif, M. A., \& Lakhani, O. J. (2020). Pandemics of the past: A narrative review. Journal of the Pakistan Medical Association, 70(5), S-34-S-37. https://doi.org/10.5455/JPMA.11

Lederer, E. M. (2020, May 8). UN chief says pandemic is unleashing a 'tsunami of hate.' The Mercury News. https://www.mercurynews.com/2020/05/07/un-chief-says-pandemic-is-unleashing-a-tsunami-of-hate/

Leung, C, et al. (2020, June). Yellow Peril Revisited: Impact of SARS on the Chinese and Southeast Asian Canadian Communities.The Chinese Canadian National Council-National Office. https://www.academia.edu/919335/Yellow peril revisited Impact of SARS on the Chinese and Southeast Asian Canadian communities

Lopez, G. (2020, September 9). How the US's Covid-19 death toll compares to other rich countries. Vox. https://www.vox.com/future-perfect/2020/9/9/21428769/covid-19-coronavirus-deaths-statistics-us-canada-europe

Madhav N, Oppenheim B, Gallivan M, et al. (2017, Nov 27). Pandemics: Risks, Impacts, and Mitigation. In: Jamison DT, Gelband H, Horton S, et al., editors. Disease Control Priorities: Improving Health and Reducing Poverty. 3rd edition. Washington (DC): The International Bank for Reconstruction and Development / Chapter 17. Available from: https://www.ncbi.nlm.nih.gov/books/NBK525302/ doi: 10.1596/978-1-4648-0527-1_ch17

Mahase, E. (2020, April 8). Covid-19: Trump threatens to stop funding WHO amid 
“China-centric” claims. The BMJ. https://www.bmj.com/content/369/bmj.m1438.full

Marquardt, A., \& Hansler, J. (2020, March 26). US push to include "Wuhan virus" language in G7 joint statement fractures alliance - CNNPolitics. CNN. https://edition.cnn.com/2020/03/25/politics/g7coronavirus-statement/index.html

McNeil, D. G. (2010, November 20). Cholera's Second Fever: An Urge to Blame. The New York Times. https://www.nytimes.com/2010/11/21/weekinreview/21 mcneil.html?auth=login-email\&login=email

Meng Introduces Legislation to Combat COVID-19 Hate Crimes. (2020, May 7). [Press release]. https://meng.house.gov/media-center/press-releases/meng-introduces-legislation-to-combat-covid-19-hatecrimes.

Ollove, M. (2020, August 18). How Misinformation, Federalism and Selfishness Hampered America's Virus Response. The Pew Charitable Trusts. https://www.pewtrusts.org/en/research-and-analysis/blogs/stateline/2020/08/18/how-misinformation-federalism-and-selfishness-hampered-americas-virus$\underline{\text { response }}$

Person, B., Sy, F., Holton, K., Govert, B., Liang, A., \& National Center for Infectious Diseases/SARS Community Outreach Team (2004). Fear and stigma: the epidemic within the SARS outbreak. Emerging infectious diseases, 10(2), 358-363. https://doi.org/10.3201/eid1002.030750

Ruiz, N. G., Horowitz, J. M., \& Tamir, C. (2020, July 1). Many Black and Asian Americans Say They Have Experienced Discrimination Amid the COVID-19 Outbreak. Pew Research Center's Social \& Demographic Trends Project. https:/www.pewsocialtrends.org/2020/07/01/many-black-and-asian-americans-say-they-have-experienced-discrimination-amid-the-covid-19-outbreak/

Safety and Health Topics | COVID-19 - Background | Occupational Safety and Health Administration. (2020). US Department of Labor. https://www.osha.gov/SLTC/covid-19/background.html

Singal, J. (2020, May 8). The Theory That Explains the Politicization of Coronavirus. Intelligencer. https://nymag.com/intelligencer/2020/05/the-theory-that-explains-the-politicization-of-coronavirus.html

Smith, M. R., Weber, L., Recht, H., \& Ungar, L. (2020, August 17). Politics slows flow of US virus funds to local public health. AP NEWS. https://apnews.com/33228796a8a66a50546c9e3ddacfef1b?utm source=facebook

Suddath, C. (2010, October 26). Top 10 Terrible Epidemics. TIME.com. http://content.time.com/time/specials/packages/article/0,28804,20274792027486 2027497,00.html

The Illness Now Has a Name: COVID-19. (2020, March 12). The New York Times. https://www.nytimes.com/2020/02/11/world/asia/coronavirus-china.html?ac$\underline{\text { tion }=\text { click } \& \text { module }=\text { Top } \% 2 \text { BStories \&pgtype }=\text { Homepage }}$

The New York Times. (2020, September 30). Covid World Map: Tracking the Global Outbreak. 
The New York Times. https://www.nytimes.com/interactive/2020/world/coronavirus-maps.html

Trauner, J. (1978). The Chinese as Medical Scapegoats in San Francisco, 1870-1905. California History, 57(1), 70-87. doi:10.2307/25157817

Tumpey, A. J., Daigle, D., \& Nowak, G. (n.d.). Communicating During an Outbreak or Public Health Investigation. Centers for Disease Control and Prevention. https://www.cdc.gov/eis/field-epi-manual/chapters/Communicating-Investigation.html

VOA News. (2020, June 22). WHO Chief Says “Politicization” of Pandemic Hurting Global Efforts. Voice of America. https://www.voanews.com/covid-19-pandemic/who-chief-says-politicizationpandemic-hurting-global-efforts

Vox. (2020, May 22). One reason why coronavirus hits Black people the hardest [Video]. YouTube. https://www.youtube.com/watch?v=XAFD-0aMkwE

Wilford, J. N. (2008, April 15). How epidemics helped shape the modern metropolis. New York Times. https://www.nytimes.com/2008/04/15/health/15iht-15chol.11988148.html

Weissert, W., \& Lemire, J. (2020, May 7). Face masks make a political statement in era of coronavirus. AP NEWS. https://apnews.com/7dce310db6e85b31d735e81d0af6769c

Working Class History. (2020). Racism Epidemic in History. Collecteurs | The Museum of Private Collections. https://www.collecteurs.com/essay/racism-epidemic-in-history

World Health Organization. (2007, April). Mass Casualty Management Systems | Strategies and guidelines for building health sector capacity. https://www.who.int/hac/techguidance/MCM inside Jul07.pdf

Yong, E. (2020, August 6). Why the Pandemic Is So Bad in America. The Atlantic. https://www.theatlantic.com/magazine/archive/2020/09/coronavirus-american-failure/614191/ 